\title{
Restrictions of process machine retooling at machine-building enterprises
}

\author{
Elena Kuznetsova ${ }^{1, *}$, Ludmila Tipner $^{1}$, and Alexey Ershov ${ }^{1}$ \\ ${ }^{1}$ Mechanics and Machine Building Institute, Ural Federal University, Russia
}

\begin{abstract}
The competitiveness of the national economy depends on the technological level of the machine-building enterprises production equipment. Today in Russia there are objective and subjective restrictions for the optimum policy formation of the manufacturing equipment renewal. The analysis of the manufacturing equipment age structure dynamics in the Russian machine-building complex indicates the negative tendencies intensification: increase in the equipment service life, reduction in the share of up-todate equipment, and drop in its use efficiency. The article investigates and classifies the main restrictions of the manufacturing equipment renewal process, such as regulatory and legislative, financial, organizational, competency-based. The economic consequences of the revealed restrictions influence on the machinebuilding enterprises activity are shown.
\end{abstract}

\section{Introduction}

Productions with a high intellectual component in the capital structure, with the elements of new technological ways, form an economic core of any country. The machine-building industry as the multiplier of the economic system development for any territory belongs to such productions. The availability and effective use of mechanical engineering enterprises production capacity is a key to the national economy competitiveness, and the strategy of its use defines the growth path of the economy, innovative prospects, and the possibilities of its development on a modern hi-tech basis.

In the economically developed countries from 30 to $55 \%$ of the total amount of industrial output release falls on the share of the machine-building productions (in Germany - 53,6\%, Japan - 51,5\%, England - 39,6\%, Italy - 36,4\%, China - 35,2\%). In the developed countries profit from the machine-building field provides full modernization of the industry every 8-10 years [1]

The modernization of the Russian industrial enterprises is one of the main problems now: some enterprises need to restore their lost productions, for some the task is innovative development on the basis of complex modernization, for others effective cooperation interactions. For the machine-building enterprise as the minimal structural unit of the economy, independently conducting its production, economic and reproduction activity [2], the recovery function is one of the most important, i.e. the independent distribution of the income from sales, ensuring the spent material, labor, financial and other resources reproduction. The recovery function means the constant need for the product development, which requires modernization and update of the production capacity. Therefore the problem of the manufacturing equipment renewal is relevant for the enterprises which update the production potential, restore it or create cooperation communications to provide the most effective equipment utilization.

The age structure of the equipment used in the mechanical engineering of the Russian Federation is presented in Fig. The average age of the equipment during the last five-years is more than 20 years while the life cycle of the modern hi-tech equipment is 7-8 years.

According to the Ministry of Economic Development of the Russian Federation, in general, until 2025 the domestic economy will require about 2.5 trillion dollars of investments. By the estimates of independent experts, not less the fifth part from this sum should be spend on renewal of the basic productive assets.

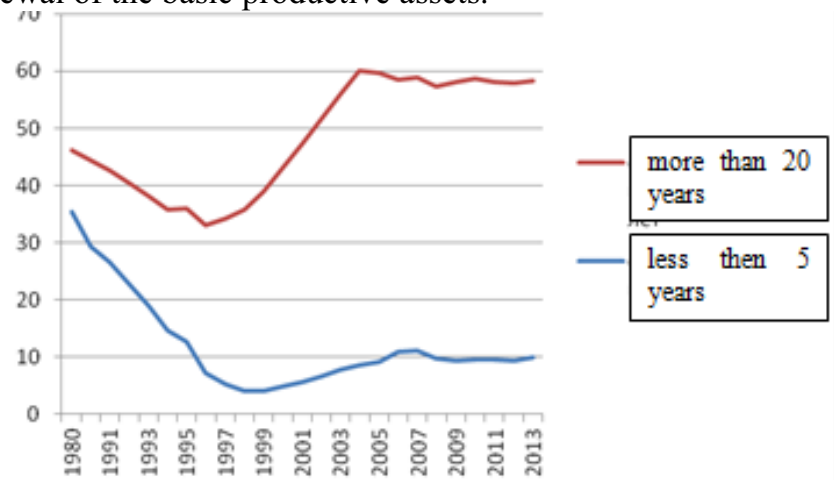

Fig. 1. Dynamics of the mechanical engineering production equipment age structure in the Russian Federation [3].

The average percent of the basic assets renewal on the start of the market relations development in the Russian Federation had been about $10 \%$, in the $90 \mathrm{~s}$ it decreased to $1-2 \%$. After 2005 the coefficient of funds renovation increased to $5 \%$ and practically stabilized.

Corresponding author: elena.bstm@gmail.com

(C) The Authors, published by EDP Sciences. This is an open access article distributed under the terms of the Creative Commons Attribution License 4.0 (http://creativecommons.org/licenses/by/4.0/). 
Now the question of the production assets modernization took on strategic importance.

It should be noted that the problem of the production assets modernization is not new to the Russian economy.

In the post-war years, in the 1950-60s, this problem was studied and discussed by the Soviet scientists Bunich P.G. - problems of basic assets depreciation [4,5], Ivanov E.A. - problems of reproduction and use [6], Strumilin S.G. - questions of functional depreciation of the equipment [7].

In the 70-80s the specific features of the Russian (Soviet) mechanical engineering were the following: it made machines and equipment practically for all industries, acting as the initiator of the fixed capital renovation. And the discussion of the modification questions by scientists and experts was absolutely natural: Palterovich D. M., Zakharov V. G., Baranov D. A., Khachaturov T. S. $[8,9,10,11]$ dealt with this issue in the seventies; V. P. Krasovsky, V. M. Rimer, M. M. Goldin in the eighties $[12,13,14]$; N. M. Alekseenko, V. Ivanchenko in the nineties $[15,16]$.

It is important to note the Ural school of sciences, which was completely devoted to the analysis, studying and forecasting of problems, connected with intra productive reserves and, in particular, with the problems of capacities proportionality and equipment use efficiency, that is reflected in works $[17,18]$. Already in the mid-nineties the problem of modernization and technical renovation began to be considered not as a task, but as a pressing problem at the level of the country: I. Ivanov, S. Rogov [19]

Obviously, today the Russian machine-building enterprises need to mobilize all available resources (both internal and external) considering the starting condition level of the manufacturing equipment. Many enterprises will be able to count on full support from the state. The role of the state as the main agent of modernization is specific characteristic for all modernization strategies of the end of 19th and 20th century. The governments of the different countries including Russia use a set of economic mechanisms to support the productive assets modernization of the enterprises: funding and direct financing of projects, administration of credit guarantees, tax preferences and support on the legislative level.

The difficult process of the production equipment renewal has the main restrictions: regulatory and legislative, financial, organizational, competence-based.

\section{Regulatory and legislative restrictions of the technical equipment renewal process}

Some laws can be classified as the regulatory and legislative restrictions. As the Federal law of 18.07.2011 No. 223-FZ "On Procurement of Goods, Works and Services by Certain Legal Entities" [20], and the Federal law of 05.04.2013 No. 44-FZ "On the System of Public Procurement Contracts for Products, Works, Services for State and Municipal Needs" [21] assume realization of the following obligatory procedures:

- carrying out public purchases;
- drawing up and approving the Provision on procurement by each enterprise;

- publication of plans of innovative and hi-tech products procurement for 5-7 years. It should be noted that the business community suggests canceling this restriction as impracticable and risky for the companies. The establishment of the requirement to the publication of short-term plans of innovative and hi-tech products procurement is possible;

- monitoring, audit of the market;

- choice of procurement way at different cost;

- creation of contract service (the contract managing director), which raises expenses of the enterprise;

- creation of the commission on acceptance of the performed works results.

It involves the following consequences:

- expenses increase of the organizations- customers (due to the need of drawing up documentation about purchases, implementation of procurement procedures, etc.)

- increase in transactions terms;

- fall in efficiency;

- expenses increase of the organizations- customers

Public procurement in Russia is an expensive arrangement. Trying to reduce corruption in this sphere, the authorities preferred to complicate technical procedures and document flows for state customers and suppliers. But expenses of the customer during the procurement in the Russian Federation are much higher, than in the EU. The formalized procedure of the public procurement is inefficient for simple inexpensive contracts.

Fight "for honest procurement" led to the adoption of two quite similar laws within two years. The later law [21] along with the introduction of the wider range of procurement ways imposed many additional requirements on customers, including the detailed planning of procurement, justification of initial prices, efficiency monitoring and audit of the procurement. In this regard the question of procurement expenses gained sharp relevance.

During the last years the efforts of officials, businessmen and economists were directed on making the system of public procurement in the country less corrupted and more effective and transparent. Thus in numerous discussions about public procurement the primary attention was paid to the competition increase and prices reduction at the auction. Costs which are incurred by customers, suppliers and regulators (FAS Federal Antimonopoly Service, industry departments, regional departments of procurement), as a rule, were not considered.

O. Balayeva, A. Yakovlev, L. Korobeynikova and E. Chupandina [22] analyzed the costs of public procurement in Russia and compared the efficiency of various procurement procedures and types: auctions, quotations, purchases from the single supplier (calculations were made on the example of specific organization). The most expensive way of the procurement implementation was an electronic auction 174 man-hours or 35,5 thousand rubles. The signing of the direct contract with the supplier on average took 62 
man-hours or 12,7 thousand rubles. However, the relative expenses of holding the auction was only $1,4 \%$ of the auction cost against $8 \%$ for quotations and $5,7 \%$ for purchases from the single supplier.

The state institution in Russia is obliged to carry out competitive procedures if the volume of purchase exceeds 100 thousand rubles. However the Russian customers cost prefer to carry out formal procedures for smaller contracts too to avoid questions upon audit and possible charges of corruption. As a result of expenses for small purchases make about $20 \%$ of their cost. For averages purchases, by Russian standards, (100-500 thousand rubles) this indicator decreases to $6,2 \%$. And only for large procurements (over 500 thousand rubles) it reaches $1,1 \%$ of cost. For comparison: by the legislation of the European Union competitive procedures are required for contracts over 125 thousand euros worth. The authors explain so strong divergence in the level of relative expenses of procurements in Europe and in Russia by those distinctions in obligatory procedures.

The conclusion is that the application of the formalized procurement procedures are economically justified for large purchases and it is not necessary to regulate small procurements in details. It is necessary to trust more to the customers - controlling resulting effects of their activity instead of a detailed regulation of their current administrative decisions.

\section{Financial restrictions}

Limited resource of own funds. Own funds that the enterprises can spend on modernization is a profit after tax payment and the sum of accumulated depreciation. In relation to profit shareholders should make a decision (if the enterprise is a joint stock company) about its distribution. The owners often have a temptation to distribute the received result of the enterprise activity only on dividends payment and on their needs.

The empirical analysis of the Sverdlovsk region enterprises has showed that the limited number of owners who can agree about priorities (or there is a single owner) are the most successful in respect of production capacity creation of the enterprise, because they rigidly divided spheres of responsibility among themselves and observe these arrangements. In this case the decision is made in favor of technical modernization because the owner understands the technology of a production activity and accurately understands that funds of the enterprise, first of all the equipment - are prone to physical deterioration and obsolescence, and demand updating. It is worth reminding that in the Soviet Union the production development funds creation have been fixed on the legislative level since 1965, this funds were used strictly for renovation.

The depreciation deductions are more flexible and available resource, but at the existing deterioration level of fixed capital stock do not provide even simple reproduction, not to mention expanded renovation and modernizations [23].

Borrowed funds are rather expensive. At the present time the average percent of the bank credit is $20-25 \%$.
As the profitability of the majority of the processing enterprises does not exceed $10 \%$, it is clear why the credits are inaccessible for them. The enterprises carry out the simple renovations at the expense of own funds, and investment programs are compelled to curtail due to the lack of long-term resources.

Banks act like usurious offices, and give the credits to natural person under the rate from 20 to $70 \%$ per annum; the Russian banks have no means for the longterm credits, and the credits for the modernization and technical renovations are, undoubtedly, the long-term credits which are unprofitable for our banks. The main direction of the banking sector for the industrial enterprises is the crediting of current assets and current activity of the enterprises which does not bring updates and increase of production profitability. In this situation the bank credit is a means necessary to ensure the operability of the enterprise. But in the view of financial resources freezing due to the growing debt of the enterprises for the outstanding credits, the banking system needs replenishment of its capital so it resorts to the external loans. The crisis situation of 2008-2009 showed the paradox when the state allocated the funds for competitiveness maintenance to banks, but this money did not reach the enterprises. Moreover, in the crisis of 2008/09 the enterprises which used borrowed funds in the activity, suffered the most. Banks did not restructure the debts of the enterprises, and, on the contrary, toughened the "game rules", and demanded to return the credits urgently, or reconsidered terms of credits towards increase in the credit load for the enterprises.

The operational difficulties regarding finance which can impose restrictions on the renovation process realization are as follows. At the beginning of a year it is objectively more difficult to obtain the credit, than in the middle or the end of the year, even if the enterprise has positive credit history. The reason is the obligatory requirement of the bank to provide the annual account. If the enterprise is planning to receive the credit in the beginning of the year, it is necessary to minimize the time of accounting reports preparation as it is the obligatory requirement of the bank.

Sufficiency of means for a co-financing. Banks, as a rule, do not approve applications on the projects financed only by loan resources: the co-financing is welcomed. Own funds should cover the start of the project and project services, for example, the most obvious payments on the start of the project are:

- advance payments to the supplier of the equipment;

- covering of the production space preparation, personnel and permission documents costs;

- interest repayment until the project reaches a profitable zone. As a rule, the bank grants a delay in the primary loan repayment, but the debt service (payment of interest) begins in the month following the loan receipt.

Also the correct costs planning on modernization belongs to the financial restrictions. There are explicit costs which can be planned rather accurately. They are:

- equipment cost,

- equipment delivery, 
- customs registration,

- installation;

- dismantle of the old equipment;

- preparation and service of production spaces;

- retraining of the personnel to work with new equipment.

It is hard to plan the hidden expenses while preparing the technical modernization project, but in certain cases they can make a considerable sum. As the hidden expenses it is possible to consider the following:

- costs of the project and permission documents connected with the new equipment and production volume,

- commercial costs connected with the need of increase in sales,

- costs of support personnel retraining, requalification or reduction;

- costs of new employees hiring;

- costs of the infrastructure modernization which is directly connected with the new equipment (electricity, gas supply, ventilation, etc.);

- expenses on new types of raw materials (if the new equipment assumes changes in technology);

- costs of development and experimental samples production;

- expenses on production downtime (if there is no opportunity to mount the new equipment, without stopping the old).

In general, the restriction of financial character is the long term of return expectation from investment resources.

\section{Organizational restictions}

The global organizational restriction is the need of complex, system account of technical modernization.

The modernization of the enterprises includes the replacement of the equipment, along with operating conditions changes in the infrastructure of the enterprise. The optimization of the logistic scheme has a key value during the technical modernization: interaction with partners, suppliers, consumers, many of them can be new to the enterprise, or new requirements are imposed to the old partners. It is possible to achieve $15 \%$ increase in productivity by the correct labor organization and logistics without additional investments into the technical equipment replacement. The enterprise can get especially unsatisfactory effect, when it passed through the technical renovations, but did not receive worthy results because of the invalid interaction with partners. In absence of the advanced organizational technologies, the purchase of new equipment can appear inefficient waste of the invested funds. The solutions of infrastructure problems, adjustment of a mutually advantageous data exchange between the enterprises are required.

Situational, but not less important organizational restrictions are as follows.

Taking into account balance capacities on different stages. The replacement of the equipment can be carried out at the separate stages of production or cover all of them. Before choosing full or stage-by-stage modernization it is necessary to analyze the productivity of each phase to find the reserve capacities and bottlenecks.

The reserve capacities are necessary for providing the production program if in the result of the technical modernization, the productivity of the equipment, providing the leading process, increased.

The bottlenecks slow down the production, and as the result of modernization, the bottlenecks can be displaced. To avoid this, the design group, working on the organizational segment of the modernization project, should include competent engineers.

If the separate stages of the production works have incomparable productivity (power, capacity), it makes sense to carry out stage-by-stage modernization to increase capacities of the low-productive stages. This approach can lead to the situation, when the enterprise will be in the condition of the constant modernization, but on other hand - it demands less lump investments and allows mastering them gradually, as receiving positive results.

It must be kept in mind that any proposition on increase in equipment work intensity can be considered only at the account of relevant information on the equipment utilization with maintenance and repair work, and about permissible load on the personnel.

While calculation the payback of the investment project, if only part of the industrial complex of the enterprise is exposed to the technical modernization (the most often case in practice), the calculation should be performed, based on the smallest power.

Environmental standards account. Also it is necessary to pay the most thorough attention to the compliance of the planned capacities to environmental standards and requirements of the supervisory authorities.

Extra time account. Strangely enough, technical services are inclined to underestimate the duration of the installation period and trial operation of the updated equipment.

At calculation of the delivery time of the equipment it is necessary to consider the term of transportation, customs passing and other specific factors like features of the national calendars (Christmas vacation, day-offs, holiday seasons, etc.).

The special place in the "organizational" restrictions of the technical modernization should be allocated for the work of marketing service

If before the modernization project the enterprise was in the market with the un-filled capacity (pent-up demand), the enterprise is in an advantageous market position: the modernization will increase the productivity and outputs; the quality of a product, as expected, will improve.

The situation demands marketing services activity when, as the result of the modernization, the productivity and outputs increase, and, so the enterprise plans to expand its presence in the already tapped markets or take on a new one. The task of the market analysis service is to find out the existing and potential demand. In case of need, the service of realization has to increase the 
production sales volume. If the enterprise does not meet the solvent demand in the market, most likely, the schedule of the credit payments will be broken.

The developed tendency in the market of industrial production also should be kept in mind: the mass markets are inaccessible to the Russian industrial enterprises, and the batch production assumes the formation of the range dynamics based on careful market analysis and anticipatory demand management of the consumer.

\section{Competence-based restrictions}

It is necessary to mark the competences, necessary during the design and start of the project. The competences of the technical modernization process designer are internal which should be looked for in the internal environment of the enterprise. Practice shows, that this is the task for the economist and engineer, who is an expert both in "old" and "new" technological process and in the corresponding equipment. The most important aspect of the effective modernization realization is a qualitative preparation and drawing of the requirements specification which is defining for the development of pre-project and project documentation on the reconstruction and modernization [24]. Is something is missed at this stage it is difficult to fill it during the subsequent works,

The modern modernization assumes replacement of the universal equipment by specialized which demands absolutely different competences from the workers and service personnel, therefore it the work on search and attraction of "external competences" becomes important. The modern equipment mainly consists of machines with PNC. The operating modes and shift system are written by the technologist-programmer. The machine operator does not interfere with the process; he only needs to look after the work of the equipment. The control, repair, service of the machine is the competence of the service personnel. The modern hi-tech equipment demands special services for maintenance of its exact capabilities: it is necessary to clean, wipe, carry out it regularly autonomous service, to observe culture of the production. At the different enterprises the process is organized differently, but all these competences should be provided. The search of the personnel with the corresponding qualification is a project task: there is a shortage of the competent workers, capable to operate the modern hi-tech equipment in the labor market. The alternative is the preparation of the personnel by the enterprise «for the modernization". The solution of this task demands time which should be considered.

\section{Conclusion}

In the long term outlook the modernization is a guarantee of the enterprise competitiveness, growth of innovation, labor productivity and production quality.

The dynamics of the technological innovations, movement indicators and condition of the basic productive assets give the grounds to claim that the revealed restrictions do not allow solving the problem of the complex modernization fully.

\section{References}

1. V.N. Polovinkin, A.B. Fomichev, Current state and problems of a domestic machine-building, Gasweek, weekly review, 4.07.2013.

2. B. Kleyner, Bulletin of the Samara gosudastvenny university, 123, 26-35 (2015)

3. O.V. Karasuntseva, Formation and realization of strategy of increase of level of use of production capacity of the enterprises of mechanical engineering (Samara, 2014)

4. P.G. Bunich, Depreciation of fixed assets in the industry (Gosfinizdat, Moscow, 1957)

5. P.G. Bunich, Efficiency of use of fixed assets (Finance, Moscow, 1966)

6. E.A. Ivanov, Reproduction and use of fixed assets (Economy, Moscow, 1968)

7. S.G. Strumilin, Economy Questions, 8, 2-16 (1956)

8. D.M. Palterovich, Fixed assets: intensification of use and updating (Knowledge, Moscow, 1974)

9. V.G. Zakharov, Scientific and technical revolution and updating of fixed assets (Lenizdat, Leningrad, 1973)

10. D.A. Rams, Terms of depreciation and updating of the fixed business assets questions of the theory and methodology (Science, Moscow, 1977)

11. T.S. Khachaturov, Economy questions, 3 (1973)

12. V.P. Krasovsky, Compensation of fixed assets in the conditions of an intensification (Economy, Moscow, 1986)

13. M.I. Rimera, Management of use of fixed assets in the industry (Economy, Moscow, 1985)

14. M.M. Goldin, An obsolescence of fixed assets of the enterprise in the conditions of a scientific and technological revolution (Economy, Moscow, 1986)

15. N.M. Alekseenko, Reproduction of fixed assets of the industry and efficiency of their use (Lvovizdat, Lviv, 1990)

16. V. Ivanchenko, The economist, 11, 15-21 (1994)

17. K.F. Oyner, Improvement of management of fixed assets and capacities of the enterprises of mechanical engineering (Publishing house Urals, 1986)

18. V.N. Smagin, Economy assessment of technical progress and updating of cars (Chelyabinsk, 1987)

19. I. Ivanov, S. Rogov, The Russian economic magazine, 7, 20-31 (1995)

20. The federal law of 18.07.2011 No. 223-FZ About purchases of goods, works, services by separate types of legal entities. http://base .garant.ru/12188083/

21. The federal law of 05.04.2013 No. 44-FZ About contract system in the sphere of purchases of goods, 
works, services for ensuring the state and municipal needs. http://base .garant.ru/70353464/

22. O.N. Balayeva, L.S. Korobeynikov, E.E. Chupangding, A.A. Yakovlev, University management, 2 (2014)

23. I.V. Yershov, E.V. Cherepanov, Formation of effective depreciation policy of the industrial enterprise, Messenger of mechanical engineering (Scientific and technical publishing house Mechanical engineering, Moscow, 2011)

24. E.Yu. Kuznetsova, E.A. Chopovda, Messenger URFA. Economy series and management, 2, 27-35 (2013) 